\title{
A fatal case of daclizumab-induced liver failure in a patient with MS
}

Mark Stettner, MD, PhD,* Catharina C. Gross, PhD,* Anne K. Mausberg, PhD, Refik Pul, MD, Andreas Junker, MD, Hideo A. Baba, MD, Andreas Schulte-Mecklenbeck, PhD, Heinz Wiendl, MD, Christoph Kleinschnitz, MD,* and Sven G. Meuth, MD, PhD*

Neurol Neuroimmunol Neuroinflamm 2019;6:e539. doi:10.1212/NXI.0000000000000539

Daclizumab (DAC; Zinbryta) is a humanized monoclonal antibody directed against the IL-2 receptor alpha chain and was approved for treatment of relapsing-remitting MS (RRMS) in May 2016. In March 2018, DAC has been withdrawn from the market, after the fatal case of severe liver failure described here and 12 other cases ( 3 of them fatal) of serious inflammatory brain disorders including encephalitis and meningoencephalitis. Notably, most of the cases occurred in Germany, ${ }^{1-4}$ most likely because DAC received only a third-line approval by the US Food and Drug Administration.

Here, we present the fatal case of a 26-year-old woman with severe liver failure after a 4-month therapy with DAC that had been initiated 5 months after the first diagnosis of RRMS during which the patient presented severe and unusually high disease activity (expanded disability status scale [EDSS] score of 5.5). On first diagnosis, the presence of thyroid peroxidase $(92 \mathrm{U} / \mathrm{L})$ and thyroglobulin antibodies indicated a comorbidity with Hashimoto disease. Although liver enzyme counts including aspartate transaminase (AST, 42 U/L) and alanine transaminase (ALT, $84 \mathrm{U} / \mathrm{L}$ ) doubled within the 2.5 weeks prior DAC initiation, values normalized prior to first administration of the drug and remained stable during the treatment. A decreased EDSS score of 4.5, assessed after 4 months, confirmed the patient's response to treatment.

Three weeks after receiving the fourth dose of DAC, the patient developed fatigue and jaundice with significantly increased AST $(3,041 \mathrm{U} / \mathrm{L}$; reference $<35 \mathrm{U} / \mathrm{L})$, ALT $(4,760 \mathrm{U} / \mathrm{L}$; reference $<35 \mathrm{U} / \mathrm{L})$, lactate dehydrogenase $(628 \mathrm{U} / \mathrm{L}$; reference $<215 \mathrm{U} / \mathrm{L})$, and total bilirubin $(21.5 \mathrm{mg} / \mathrm{dL}$; reference $<1.1 \mathrm{mg} / \mathrm{dL})$ values. Two days later, she was hospitalized in a somnolent state with jaundice, arterial hypotension, and lactate acidosis. Diagnosis of acute irreversible liver failure prompted a high urgency liver transplantation that was performed the following day, after receiving approval by the ELAC (Eurotransplant Liver Advisory Committee) audit. One day after transplantation, the patient developed circulatory instability and catecholamine dependency with continuous peaks of transaminases (AST: 8,568 U/L; ALT: 4,207 U/L). Despite intensified treatment, the patient died 4 days later because of systemic inflammatory response syndrome, septic shock, and multiple organ failure.

We suspected DAC-induced hepatic (DIH) injury possibly owing to natural killer (NK)-cell hyperactivation, because drug reaction with eosinophilia and systemic symptoms (DRESS) and other causes of hepatic injury, including alcohol and drug abuse or viral hepatitis, could be excluded. A contribution of tizanidine, which was administered as co-medication after the fourth cycle of DAC treatment and has also been shown to induce serious liver injury as

\author{
Correspondence \\ Dr. Stettner \\ mark.stettner@uk-essen.de
}




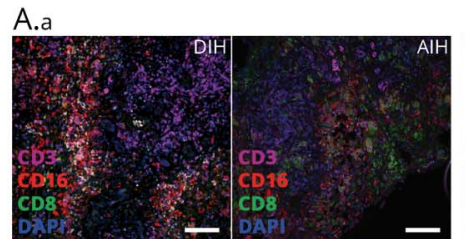

A.d

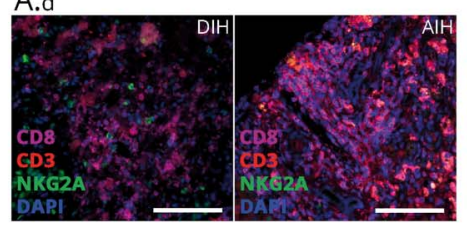

A.b

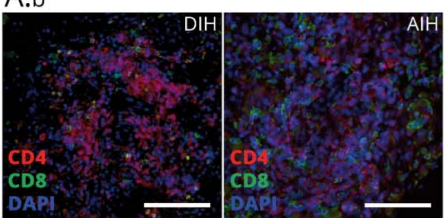

A.e

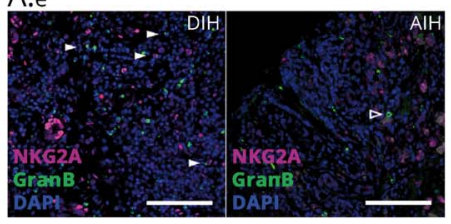

A.c

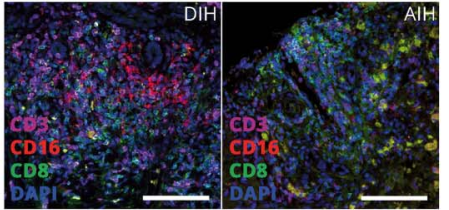

A.f

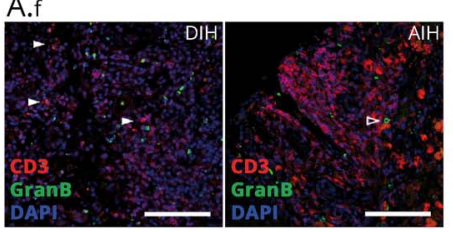

B.a. DAC BL lymphocytes

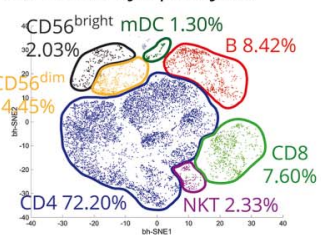

B.e. $B$ cells

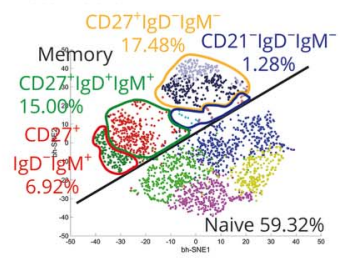

B.b. DAC 3M lymphocytes

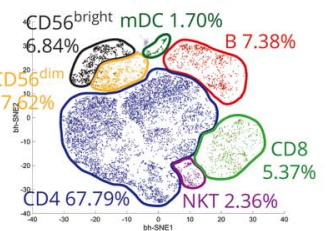

B.f. B cells

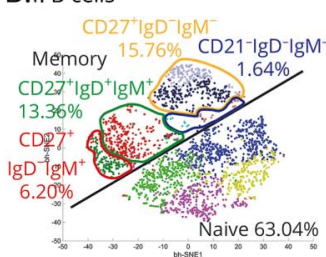

B.c. DIH lymphocytes

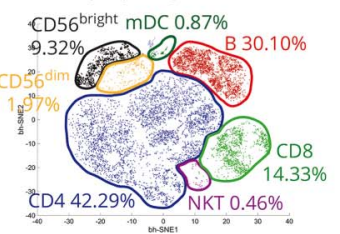

B.g. B cells

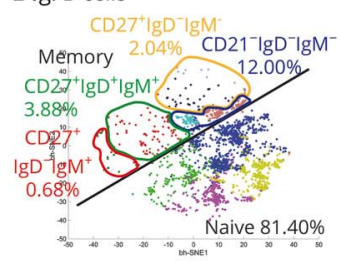

B.d. AlH lymphocytes

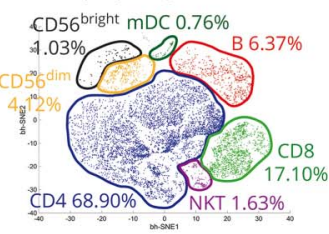

B.h. B cells

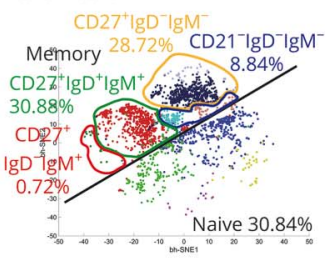

C

CD56 dim

MFI DNAM-1

CD56 bright

MFI DNAM-1

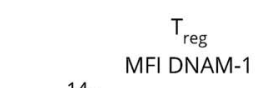

D

CD4 memory GM-CSF
CD8 memory GM-CSF
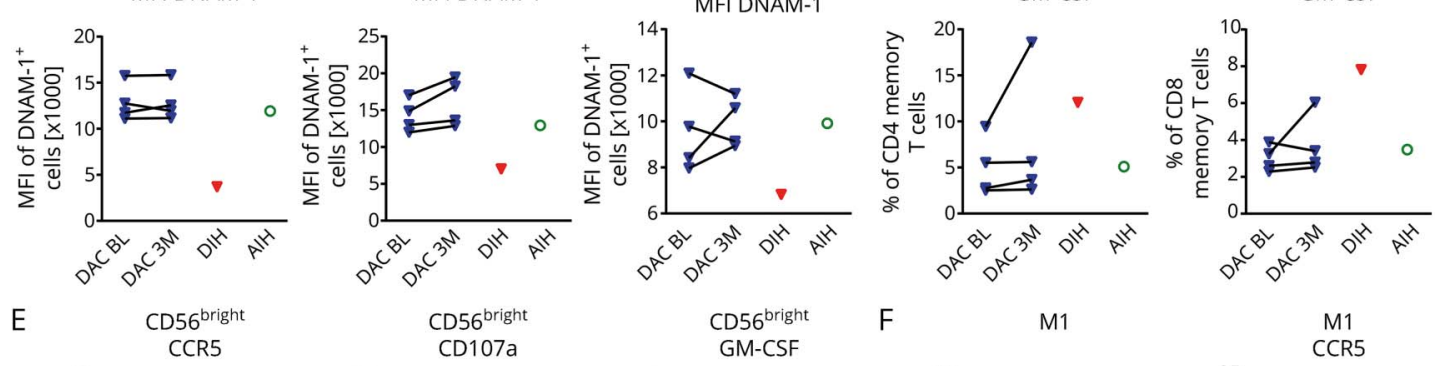

CD107a
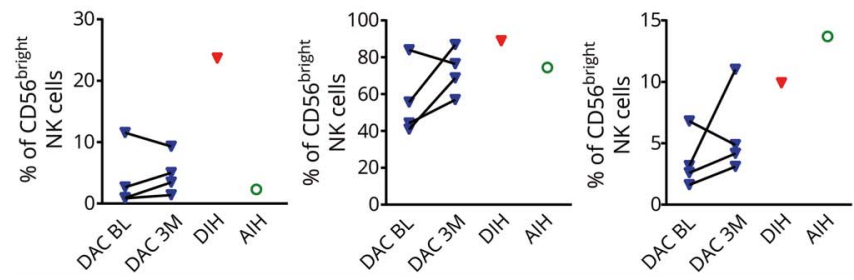

F

M1
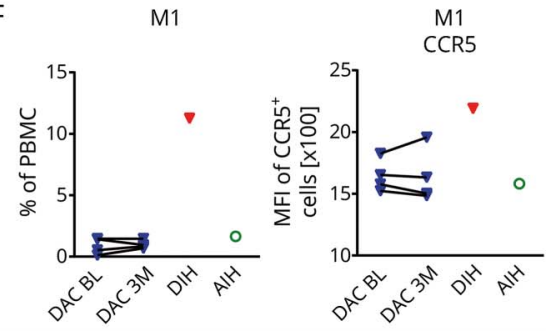

(A) Immunohistochemical detection of leukocyte infiltration in the liver of the fatal case patient with DAC-induced hepatic injury (DIH) compared to the case of a 39 year-old RRMS patient with AlH but no further relevant medical conditions. At timepoint of biopsy, this patient received glatiramer acetate without any further relevant co-medications. Seven-micrometer paraffin embedded sections were stained, with anti-CD16 (macrophages, neutrophils, NK cells), anti-CD3 (T cells), anti-CD4 (Thelper cells), anti-CD8 (cytotoxic T cells), anti-NKG2A (NK cells), anti-CD19 (B cells), and granzyme B (GranB) and matching fluorochrome-labeled secondary antibodies (Alexa Fluor 488, green; Alexa Fluor 555, red; Alexa Fluor 647, purple) as indicated; nuclei were visualized using 4,6'diamidino-2-phenylindole (DAPI, blue); scale bar $100 \mu \mathrm{m}$. (A.a): Representative image of CD $16^{+}$macrophages localized around T-cell infiltration zones. (A.b): Distribution of CD $4^{+} T$-helper cells and cytotoxic CD $8^{+} T$ cells within T-cell infiltrates. (A.c): CD19 ${ }^{+}$B cells within T-cell infiltration zone. (A.d): NKG2A + CD3- NK cells within T-cell infiltration zone. (A.e and A.f) Granzyme B expression of NKG2A + NK cells (A.e) and CD3 ${ }^{+} T$ cells (A.f) on Sequential sections. (B) PBMC derived from patients with MS $(\mathrm{N}=4)$ before (DAC BL [B.a]) and after 3 months of DAC therapy (DAC 3M [B.b]) in comparison to the index case (DIH [B.c]) as well as the patient with autoimmune hepatitis (AlH [B.d]) were stained with lineage-specific (B.a-B.D) CD1C, CD3, CD4, CD8, CD14, CD16, CD19, CD56) and B-cell subset-specific (B.e-B.H) CD19, CD20, CD21, CD23, CD24, CD27, CD38, IgD, IgM) fluorochromeconjugated antibodies and acquired by flow cytometry. Lymphocytes and B cells were electronically selected and resulting data were normalized before submitting equal numbers of randomly selected cells to unsupervised cluster analysis by viSNE software. Barnes-Hut Stochastic Neighbor Embedding (bh-SNE) algorithm was used for dimensionality reduction followed by automated identification of lymphocyte (B.a-B.d) and B-cell subsets (B.e-B.H), respectively, by phenograph algorithm. (C) Median fluorescence intensity (MFI) of DNAM-1 expressing CD56dim, CD56bright, and regulatory T cells (Treg). (D) Intracellular expression of GM-CSF in CD4 and CD8 memory T cells following stimulation with leukocyte activation cocktail (PMA, ionomycin, brefeldin A). (E) Percentage of CD56bright NK cells expressing CCR5, or secreting cytolytic vesicles (CD107a+), and expressing GM-CSF as a consequence of co-incubation with HepG2 liver cells. (F) Proportion and MFI of CCR5 of monocytes with a proinflammatory M1-like phenotype. 
a monotherapy, ${ }^{5,6}$ could not be excluded. Interestingly, tizanidine was the common denominator between this case and another fatal case of DIH injury in the SELECT trial. ${ }^{5,7}$

Immunohistochemistry of the explanted liver tissue of the patient with $\mathrm{DIH}$ revealed $\mathrm{CD} 3^{+} \mathrm{T}$-cell infiltrates surrounded by damaged zones of $\mathrm{CD}^{+} 6^{+}$macrophages. The same observations were made for the liver tissue of a 39-year-old woman diagnosed with autoimmune hepatitis (AIH) 7 months after first diagnosis of MS (figure 1A) as an example of an autoinflammatory disease of both CNS and liver. While CD $4^{+}$ T-helper cells dominated in the patient with $\mathrm{DIH}$, equal numbers of T-helper and cytotoxic $\mathrm{CD} 8^{+} \mathrm{T}$ cells were observed in the AIH liver tissue. Despite the fact that autoimmune liver disease has a wide pathophysiologic spectrum, more B-cell infiltrates were detected within the T-cell zones of the patient with DIH compared to AIH. Enrichment of granzyme B-expressing NKG2A ${ }^{+}$NK-cells in the DIH liver tissue suggests an active role of $\mathrm{NK}$ cells in hepatic injury.

In accordance with enriched B-cell infiltrates in the DIH liver, immune cell profiling of the blood revealed significantly enhanced circulating B cells (figure $1 \mathrm{~B}$ ), consisting mainly of naive $B$ cells and increased proportions of autoreactive antibody expressing complement receptor (CD21) negative B cells. ${ }^{8}$ Despite a DAC-induced increase of CD56 ${ }^{\text {bright }} \mathrm{NK}$ cells, the DIH case exhibited significantly decreased proportions of $\mathrm{CD}_{5} 6^{\mathrm{dim}} \mathrm{NK}$ cells. ${ }^{9,10}$ Diminished cell-surface expression of the activating receptor DNAM-1 (DNAX Accessory Molecule-1), which has been recently identified as a crucial player in NK- and regulatory $\mathrm{T}\left(\mathrm{T}_{\text {reg }}\right)$-cell mediated control of T-cell activity, on $\mathrm{NK}^{6}$ and $\mathrm{T}_{\text {reg }}{ }^{7}$ (figure $1 \mathrm{C}$ ), suggests impaired immune regulatory function. Accordingly, proinflammatory granulocyte-macrophage colony-stimulating factor (GM-CSF) production was increased in circulating $\mathrm{T}$ cells of the patient with $\mathrm{DIH}$ (figure 1D). Increased expression of the liver homing receptor $\mathrm{C}-\mathrm{C}$ chemokine receptor type 5 (CCR5) on CD56 ${ }^{\text {bright }} \mathrm{NK}$ cells and enhanced cytotoxic function as well as GM-CSF production in response to liver cells (figure 1E) indicated expanded liver invasion and hepatotoxicity of this subset. Finally, enhanced GM-CSF levels resulting from $\mathrm{T}$ - and $\mathrm{NK}$-cell hyperactivation may drive the differentiation of CCR5-expressing proinflammatory M1-like monocytes leading to the highly increased frequencies observed in the blood of the patient with DIH (figure 1F). ${ }^{11}$ Overall, our findings indicate $\mathrm{DIH}$ injury resulting from innate immune cell activation and impaired immune regulation. Although involvement of the liver frequently occurs in DRESS, this case does not fulfill critical criteria for DRESS such as hypereosinophilia, rashes, and reactivation of herpes viruses, ${ }^{12,13}$ thus, differing from the recently described DAC-induced DRESS cases.

\section{Acknowledgment}

The authors would like to thank Steffi Hezel, Daniela Roosterman, Lena Schüneman, and Julia Sundermeier for their excellent technical assistance. The authors thank Prof. Carsten Watzl,
Leibniz Research Centre for Working Environment and Human Factors at TU Dortmund, for his suggestions regarding the hepatocyte co-culture assays. This project was funded by the German Research foundation (SFB/Transregio CRC128 projects A09 to HW and CCG and Z2 to HW) and the German Ministry for Education and Research (BMBF; project 01GI1603A to HW and CCG).

\section{Study funding}

This project was funded by the German Research foundation (SFB/Transregio CRC128 projects A09 to HW and CCG and $\mathrm{Z} 2$ to $\mathrm{HW}$ ) and the German Ministry for Education and Research (BMBF; project 01GI1603A to HW and CCG).

\section{Disclosure}

M. Stettner served on the scientific advisory board for UCB and Biogen Idec; received travel funding and/or speaker honoraria from Biogen, Genzyme, Novartis, Sanofi-Aventis, UCB, Grifols, TEVA, and Bayer; and served as an associate editor for European Journal of Medical Research. C.C. Gross received speaker honoraria and travel funding from Biogen, Euroimmun, Genzyme, Mylan, Novartis, and Bayer; served as review editor for Frontiers in Neuroimmunology; and received research support from ReSTORE German Research Foundation, BMFB, and Innovative Medical Science. A.K. Mausberg reports no disclosures. $\mathrm{R}$. Pul served on the scientific advisory board for Merck, Biogen, Bayer, and Novartis; received travel funding and/or speaker honoraria from Merck, Biogen, Mylan, TEVA, and Sanofi-Genzyme; served as guest editor for Frontiers in Neurology, Cells; and received research support for TEVA, Novartis, Merck, Sanofi-Genzyme. A. Junker, H.A. Baba, and A. Schulte-Mecklenbeck report no disclosures. H. Wiendl served on the scientific advisory board for Bayer, Biogen, Sanofi-Genzyme, Merck Serono, Novartis, Roche, and TEVA; received travel funding and/or speaker honoraria from Bayer Vita, Bayer Schering, Bioven, CSL Behring, EMD Serono, Fresenius Medical Care, SanofiGenzyme, Merck Serono, Omni-Mad, Novartis, TEVA, GlaxoSmithKline, and GW; served as an editorial board member for PLoS One, Neurotherapeutics, Recent Patents on Inflammation \& Allergy Drug Discovery; consulted for Bioge, Merck Serono, Novartis, OmniaMed, Roche, and SanofiGenzyme; and received research support from Bayer HealthCare, Bayer Vital, Biogen, Merch Serono, Novartis, Sanofi-Genzyme, Sanofi, TEVA, German Ministry for Education and Research, Interdisciplinary Centre of Clinical Research, PML Consortium, German Research Foundation, Else Kröner-Fresenius Foundation, Hertie Foundation, RE Children's Foundation. C. Kleinschnitz receives honoraria for lecturing and travel expenses for attending meeting from Amgen, Bayer HealthCare, Bristol-Myers Squibb, Boehringer Ingelheim, Biogen, Biotronik, CSL Behring, Daiichi Sankyo Genzyme, Desitin, Eisai, Ever Pharma, MedDay Pharmaceuticals, Merck Serono, Mylan, Novartis, Pfizer, Roche, Sanofi-Aventis, Siemens, Stago, and Teva; received research funding from the German Ministry for Education and Research (BMBF), Corona Foundation, Deutsche 
Forschungsgemeinschaft (DFG), Deutsche Stiftung Neurologie (DSN), Else Kroener-Fresenius Foundation, European Union, and Bayer Healthcare, Biogen, CSL Behring, Genzyme, Merck Serono, Novartis and Teva; served on the editorial board for PLoS One and Stroke; and holds a patent for Effectivity of specific FXII/FXIIa inhibitors, particularly rHAInfestin-4 used to treat neuroinflammatory diseases. S. Meuth receives honoraria for lecturing and travel expenses for attending meeting from Almirall, Amicus Therapeutics Germany, Bayer HealthCare, Biogen, Celgene, DiaMed, Genzyme, MedDay Pharmaceuticals, Merck Serono, Novartis, Novo Nordisk, ONO Pharma, Roche, Sanofi-Aventis, Chugai Pharma, QuintilesIMS, and Teva; received research funding from the German Ministry for Education and Research (BMBF), Deutsche Forschungsgesellschaft (DFG), Else Kröner-Fresenius Foundation, German Academic Exchange Service, Hertie Foundation, Interdisciplinary Center for Clinical Studies (IZKF) Munster, German Foundation Neurology and Almirall, Amicus Therapeutics Germany, Biogen, DiaMed, Fresenius Medical Care, Genzyme, Merck Serono, Novartis, ONO Pharma, Roche, and Teva; served on the editorial board for PLoS One; and holds patents for Effectivity of specific FXIIa inhibitors/FXIIa inhibitorsa inhibitors, particularly rHA-Infestin-4 used to treat neuroinflammatory diseases, Diagnosis of a novel autoimmune disease, "NR2B selective NMDA-receptor Antagonists for Treatment of immune-mediated inflammatory diseases." Full disclosure form information provided by the authors is available with the full text of this article at Neurology.org/NN.

\section{Publication history}

Received by Neurology: Neuroimmunology \& Neuroinflammation August 6, 2018. Accepted in final form December 7, 2018.

\section{References}

1. Devlin M, Swayne A, Newman M, et al. A case of immune-mediated encephalitis related to daclizumab therapy. Mult Scler 2018:1352458518792403.

2. Luessi F, Engel S, Spreer A, Bittner S, Zipp F. GFAPalpha IgG-associated encephalitis upon daclizumab treatment of MS. Neurol Neuroimmunol Neuroinflamm 2018;5:e481.

3. Rauer S, Stork L, Urbach H, et al. Drug reaction with eosinophilia and systemic symptoms after daclizumab therapy. Neurology 2018;91:e359-e363.

4. Scheibe F, Metz I, Radbruch H, et al. Drug reaction with eosinophilia and systemic symptoms after daclizumab therapy in MS. Neurol Neuroimmunol Neuroinflamm 2018;5:e479.

5. de Graaf EM, Oosterveld M, Tjabbes T, Stricker BHC. A case of tizanidine-induced hepatic injury. J Hepatol 1996;25:772-773.

6. Gill D, Allam F, Boyle J. Importance of medication reconciliation: tizanidine-induced hepatitis. Am J Ther 2017;24:e623-e624.

7. Giovannoni G, Gold R, Selmaj K, et al. Daclizumab high-yield process in relapsing remitting multiple sclerosis (SELECTION): a multicentre, randomised, double-blind extension trial. Lancet Neurol 2014;13:472-481.

8. Isnardi I, Ng YS, Menard L, et al. Complement receptor 2/CD21- human naive B cells contain mostly autoreactive unresponsive clones. Blood 2010;115:5026-5036.

9. Bielekova B, Catalfamo M, Reichert-Scrivner S, et al. Regulatory CD56(bright) natural killer cells mediate immunomodulatory effects of IL-2Ralpha-targeted therapy (daclizumab) in multiple sclerosis. Proc Natl Acad Sci U S A 2006;103: 5941-5946.

10. Gross CC, Schulte-Mecklenbeck A, Runzi A, et al. Impaired NK-mediated regulation of T-cell activity in multiple sclerosis is reconstituted by $\mathrm{IL}-2$ receptor modulation. Proc Natl Acad Sci U S A 2016;113:E2973-E2982.

11. Verreck FA, de Boer T, Langenberg DM, et al. Human IL-23-producing type 1 macrophages promote but IL-10-producing type 2 macrophages subvert immunity to (myco)bacteria. Proc Natl Acad Sci U S A 2004;101:4560-4565.

12. Cacoub P, Musette P, Descamps V, et al. The DRESS syndrome: a literature review. Am J Med 2011;124:588-597.

13. Tohyama M, Hashimoto K, Yasukawa M, et al. Association of human herpesvirus 6 reactivation with the flaring and severity of drug-induced hypersensitivity syndrome. Br J Dermatol 2007;157:934-940.

Appendix 1 Author contributions

\begin{tabular}{|c|c|c|c|}
\hline Name & Location & Role & Contribution \\
\hline Mark Stettner & $\begin{array}{l}\text { Department of Neurology, University } \\
\text { Hospital Essen, Essen, Germany }\end{array}$ & Author & $\begin{array}{l}\text { Designed and conceptualized the study; analyzed and interpreted data; and } \\
\text { drafted the manuscript for intellectual content }\end{array}$ \\
\hline $\begin{array}{l}\text { Catharina C. } \\
\text { Gross }\end{array}$ & $\begin{array}{l}\text { Clinic of Neurology, University Hospital } \\
\text { Münster, Münster, Germany }\end{array}$ & Author & $\begin{array}{l}\text { Designed the study; analyzed and interpreted data; and drafted the manuscript } \\
\text { for intellectual content }\end{array}$ \\
\hline $\begin{array}{l}\text { Anne K. } \\
\text { Mausberg }\end{array}$ & $\begin{array}{l}\text { Department of Neurology, University } \\
\text { Hospital Essen, Essen, Germany }\end{array}$ & Author & Played a major role in the acquisition and interpretation of data \\
\hline Refik Pul & $\begin{array}{l}\text { Department of Neurology, University } \\
\text { Hospital Essen, Essen, Germany }\end{array}$ & Author & $\begin{array}{l}\text { Designed the study; played a major role in the acquisition of data; and revised } \\
\text { the manuscript }\end{array}$ \\
\hline Andreas Junker & $\begin{array}{l}\text { Institute of Neuropathology, University } \\
\text { Hospital Essen, Essen, Germany }\end{array}$ & Author & Played a major role in the acquisition of data and revision of the manuscript \\
\hline Hideo A. Baba & $\begin{array}{l}\text { Institute of Pathology, University } \\
\text { Hospital Essen, Essen, Germany }\end{array}$ & Author & Played a major role in the acquisition of data and revision of the manuscript \\
\hline $\begin{array}{l}\text { Andreas } \\
\text { Schulte- } \\
\text { Mecklenbeck }\end{array}$ & $\begin{array}{l}\text { Clinic of Neurology, University Hospital } \\
\text { Münster, Münster, Germany }\end{array}$ & Author & $\begin{array}{l}\text { Played a major role in the experimental design, acquisition, and analysis of flow } \\
\text { cytometry data; designed figures; and revised the manuscript }\end{array}$ \\
\hline Heinz Wiendl & $\begin{array}{l}\text { Clinic of Neurology, University Hospital } \\
\text { Münster, Münster, Germany }\end{array}$ & Author & Interpreted data and revised the manuscript for intellectual content \\
\hline $\begin{array}{l}\text { Christoph } \\
\text { Kleinschnitz }\end{array}$ & $\begin{array}{l}\text { Department of Neurology, University } \\
\text { Hospital Essen, Essen, Germany }\end{array}$ & Author & $\begin{array}{l}\text { Designed the study; analyzed and interpreted data; and drafted the manuscript } \\
\text { for intellectual content }\end{array}$ \\
\hline Sven G. Meuth & $\begin{array}{l}\text { Clinic of Neurology, University Hospital } \\
\text { Münster, Münster, Germany }\end{array}$ & Author & $\begin{array}{l}\text { Conceptualized the study; analyzed and interpreted data; and drafted the } \\
\text { manuscript for intellectual content }\end{array}$ \\
\hline
\end{tabular}




\title{
Neurology \\ Neuroimmunology \& Neuroinflammation
}

\author{
A fatal case of daclizumab-induced liver failure in a patient with MS \\ Mark Stettner, Catharina C. Gross, Anne K. Mausberg, et al. \\ Neurol Neuroimmunol Neuroinflamm 2019;6; \\ DOI 10.1212/NXI.0000000000000539
}

This information is current as of January 21, 2019

\section{Updated Information \& \\ Services}

References

Citations

Permissions \& Licensing

Reprints including high resolution figures, can be found at:

http://nn.neurology.org/content/6/2/e539.full.html

This article cites 12 articles, 4 of which you can access for free at: http://nn.neurology.org/content/6/2/e539.full.html\#\#ref-list-1

This article has been cited by 1 HighWire-hosted articles:

http://nn.neurology.org/content/6/2/e539.full.html\#\#otherarticles

Information about reproducing this article in parts (figures,tables) or in its entirety can be found online at:

http://nn.neurology.org/misc/about.xhtml\#permissions

Information about ordering reprints can be found online: http://nn.neurology.org/misc/addir.xhtml\#reprintsus

Neurol Neuroimmunol Neuroinflamm is an official journal of the American Academy of Neurology.

Published since April 2014, it is an open-access, online-only, continuous publication journal. Copyright

Copyright (C) 2019 The Author(s). Published by Wolters Kluwer Health, Inc. on behalf of the American

Academy of Neurology.. All rights reserved. Online ISSN: 2332-7812.

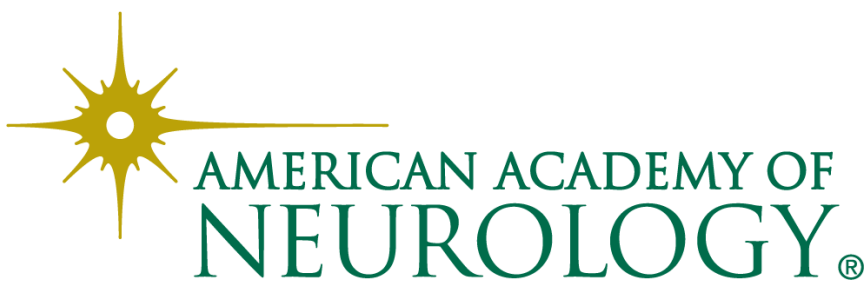

